\title{
SUPERVISION AS THE PROCEDURE APPLICABLE IN THE CASE OF BANKRUPTCY
}

\author{
A. R. Khafizova*, S. V. Salmina, L. T. Bakulina, N. E. Habibullin
}

Kazan Federal University, 18 Kremlyovskaya str., Kazan, 420008

Published online: 08 August 2017

\begin{abstract}
The article is devoted to the monitoring procedure used in the bankruptcy case. The procedures used in the insolvency (bankruptcy) case are examined and analyzed. Bankruptcy is the debtor's inability recognized by the court of arbitration or the debtor's inability to fully satisfy the creditors' claims for monetary obligations and (or) fulfill the obligation to pay mandatory payments. Insolvency a legal entity may be recognized insolvent (bankrupt), with the exception of a state enterprise, an institution, political party and a religious organization. The Institute of Bankruptcy is known to all countries with a market economy and is one of the main elements of the mechanism of legal regulation of market relations. In the process of carrying out economic activities, organizations - subjects of the market economy enter into numerous relations with each other, with state bodies, banks and other organizations. Federal Law No. 127-FZ of October 26, 2002 "On Insolvency (Bankruptcy)" provides for the following bankruptcy procedures: supervision, financial recovery, external management, bankruptcy proceedings, amicable settlement. The emphasis is on the observation procedure. The purposes of introduction of procedure of bankruptcy are allocated. Conclusions are made about the expediency of using this procedure, its advantages and disadvantages are highlighted.
\end{abstract}

Keywords: institute of bankruptcy, bankruptcy procedures, supervision, external administrator, debtor, creditor.

\footnotetext{
Author Correspondence, e-mail: author@gmail.com

doi: http://dx.doi.org/10.4314/jfas.v9i2s.86
} 


\section{INTRODUCTION}

Problem of bankruptcy of the debtor who is not fulfilling the obligations - one of the most urgent problems of civil law throughout many centuries as it is directly connected with development of the commodity-money relations and formation of the contract as the instrument of civil circulation. At non-execution by the debtor of obligations, the creditor has the right to have satisfaction of the requirements by the address of collecting of any property of the debtor. It, first, can become an absolute obstacle for continuation of functioning of the enterprise debtor; secondly, not to give the chance to other creditors, a date of performance of obligations which came later, to meet the requirements. "For the prevention of advantages on the party of the first creditor who started collecting the order of perhaps more equal and equitable distribution of property of the debtor between all his creditors" is established [8]. Such order is established within production about insolvency and is aimed at providing interests both creditors, and the debtor who has an opportunity under some conditions to restore the solvency.

Now the main normative document regulating the procedure of bankruptcy is the Federal law of October 26, 2002 N 127-FZ "About insolvency (bankruptcy)" (further in the text - the Law on bankruptcy). It more than the Law "About Insolvency (Bankruptcy) of the Enterprises" of 1998, answers modern economic realities and much in more detail governs various relations arising at bankruptcy.

Insolvency (bankruptcy) is the inability of the debtor recognized as arbitration court or announced by the debtor in full to meet requirements of creditors for liabilities and (or) to fulfill a duty on payment of obligatory payments. According to article 65 of the Civil code of the Russian Federation (further in the text - the Civil Code of the Russian Federation) insolvent (bankrupt) the legal entity, except for the state enterprise, establishment, political party and the religious organization can be by a court decision recognized.

\section{Theory}

The institute of bankruptcy is known to all countries with market economy and is one of basic elements of the mechanism of legal regulation of the market relations. In the course of implementation of economic activity of the organization - subjects of market economy enter the numerous relations with each other, with public authorities, banks and other organizations. Often these relations generate the liabilities arising from the conditions provided by the law or the contract. In case the liability undertaken by the debtor in due time is not repaid and the 
impossibility of repayment of the obligation from the cost of property of the debtor is obvious, such legal entity can be declared insolvent (bankrupt). In case of recognition of the legal entity by insolvent (bankrupt), his commercial activity stops, and the property is implemented for satisfaction of requirements of creditors [1].

It should be noted that the foreign legislation uses the term "insolvency" as there is a point of view that bankruptcy is criminally - a legal side of insolvency. In the USA the person concerning whom procedures of bankruptcy are excited during proceeding is considered insolvent, and after the judgment can be declared bankrupt. The modern Russian legislation does not differentiate the concept "insolvency" and "bankruptcy", they are used as synonyms. Meanwhile, the position of the Russian pre-revolutionary law was other. It was considered that bankruptcy is careless or deliberate causing by the poor debtor damage to creditors by means of reduction or concealment of property [12].

Elimination of insolvent debtors has positive sides as promotes a conclusion of the inefficient enterprises from economic circulation. Also positive aspect of the procedure of bankruptcy is the possibility of the debtor, having repaid the obligations at the expense of the available property, to be exempted from debts and to begin implementation of the new economic activity which is not burdened with obligations. It should be noted that recognition of the debtor by the bankrupt affects the rights and interests of a wide range of other persons - his workers, creditors and others, generates considerable social costs. Unfortunately, the procedure of bankruptcy of legal entities is often used not for restoration of solvency of the enterprise or satisfaction of requirements of creditors at all, and for the purpose of change of the property right to the liquidated enterprise. However, according to Miftakhutdinov R. T. voluntary elimination and bankruptcy as a special case of elimination at imperfection of the current legislation are even more often used not in the raider purposes any more, and for the "legalized" method of payment [5].

\section{DISCUSSION}

Now the main normative document regulating the procedure of bankruptcy is the Federal law of October 26, 2002 N 127-FZ "About insolvency (bankruptcy)". The specified law establishes the bases for recognition of the debtor by insolvent (bankrupt), regulates an order and conditions of implementation of measures for the prevention of insolvency (bankruptcy), an order and the conditions of holding procedures of bankruptcy and other relations arising at inability of the 
debtor to meet in full requirements of creditors. The law on bankruptcy is the complex act containing norms of substantive and procedural law [3].

Insolvency (bankruptcy) is the inability of the debtor recognized as arbitration court or announced by the debtor in full to meet requirements of creditors for liabilities and (or) to fulfill a duty on payment of obligatory payments [2]. According to article 65 Civil Code of the Russian Federation insolvent (bankrupt) the legal entity, except for the state enterprise, establishment, political party and the religious organization can be by a court decision recognized.

The main formal signs of insolvency of legal entities and citizens are the following:

- $\quad$ presence at the debtor of the expired liability: the requirement to the debtor citizen has to make not less than ten thousand rubles, and to the legal entity - not less than three hundred thousand rubles.

- $\quad$ non-execution of this obligation within three months;

- $\quad$ recognition by exclusively arbitration court.

It should be noted that insolvency signs for some types of economic entities, for example credit institutions and natural monopolies of fuel and energy complex, differ from a little given above. The procedures applied to the debtor represent the set of the actual and legal actions directed to restoration of solvency of the debtor or his elimination provided by the legislation. The procedures provided by the legislation can be divided into two groups: judicial and extrajudicial. So, it is possible to refer pre-judicial sanitation and the voluntary announcement of the enterprise debtor of the bankruptcy to extrajudicial procedures. Pre-judicial sanitation, according to article 2 of the Law on bankruptcy are the measures for restoration of solvency of the debtor taken by the owner of property of the debtor, the debtor's founders, creditors of the debtor and other persons for the prevention of bankruptcy. These procedures allow to resolve issues of further activity of the organization without appeal to arbitration court or to be liquidated voluntarily [6].

It is necessary to pay attention that the subject of bankruptcy is studied by such authors as Alpanda, S.a, Zubairy, S.b [9], du Jardin, P. [10], Yang, J.-Q., Yang, Z.-J. [11], Chen, D., Zhao, J. [13], Chou, C.-H., Hsieh, S.-C., Qiu, C.-J. [14], Thomson, W. [15].

When considering the case about bankruptcy of the debtor - the legal entity the following procedures which are schematically represented in the figure 1 directly are in a judicial proceeding applied. 


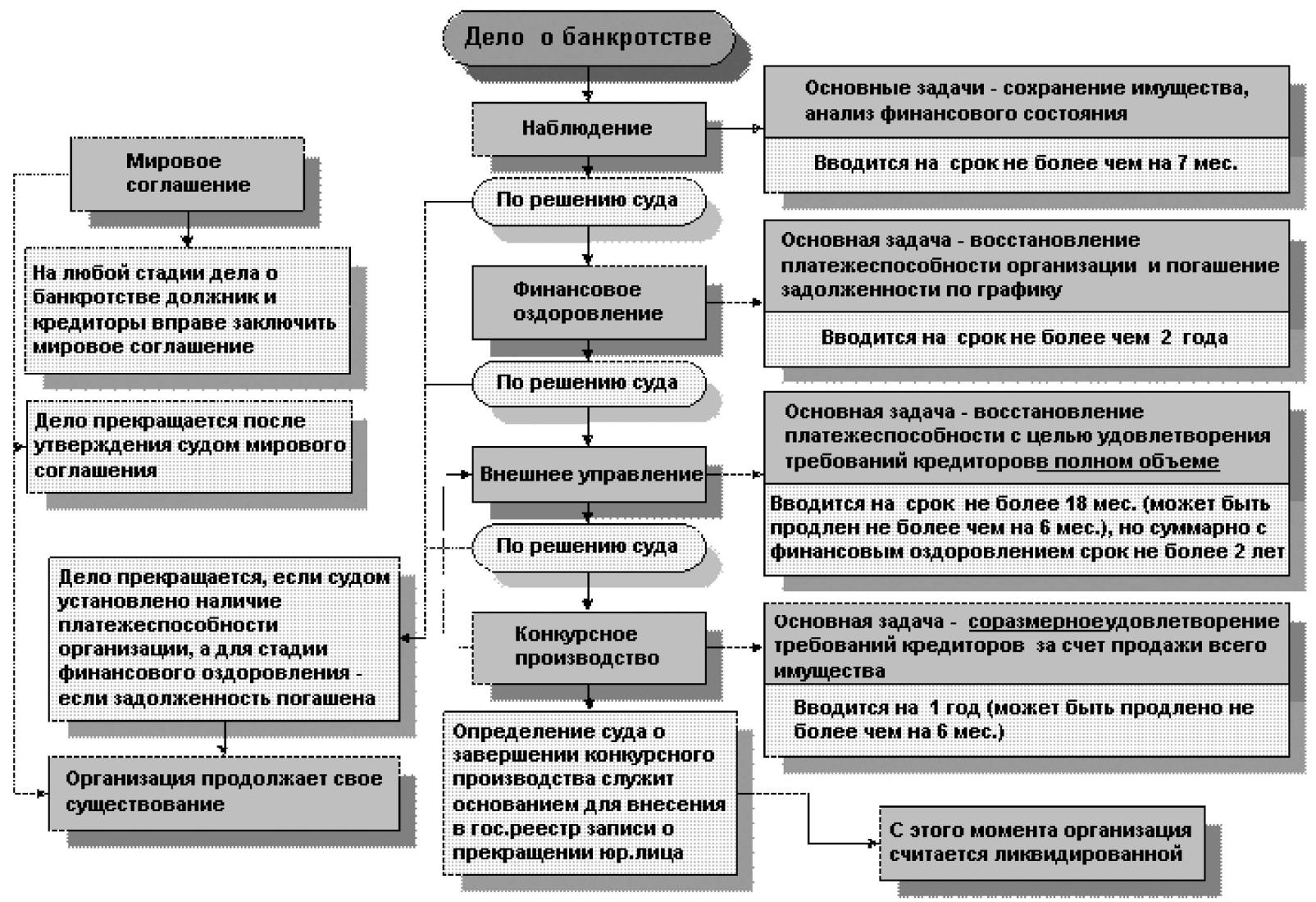

\section{Дело о банкротстве}

Мировое соглашение

На любой стадии дела о банкротстве должник и кредиторы вправе заключить мировое соглашение

Дело прекращается после утверждения судом мирового соглашения

Дело прекращается, если судом установлено наличие платежеспособности организации, а для стадии финансового оздоровления если задолженность погашена

Организация продолжает свое существование

Наблюдение

По решению суда
Case of bankruptcy

Settlement agreement

At any stage of case of bankruptcy the debtor and creditors have the right to conclude the settlement agreement

The case is dismissed after the approval by court of the settlement agreement

The case is dismissed if the court has

established existence of solvency of the organization, and for a stage of financial improvement - if the debt is repaid

The organization continues the existence Observation

By a court decision

Financial improvement 


\begin{tabular}{|c|c|}
\hline Финансовое оздоровление & By a court decision \\
\hline По решению суда & External management \\
\hline Внешнее управление & By a court decision \\
\hline По решению суда & Bankruptcy proceedings \\
\hline Конкурсное производство & Definition of court about completion of \\
\hline Определение суда о завершении & bankruptcy proceedings forms the basis for \\
\hline производства служит & entering into the state register of record about \\
\hline основанием для внесения & the termination of the legal entity \\
\hline $\begin{array}{l}\text { государственный реестр записи о } \\
\text { прекращении юридического лица }\end{array}$ & $\begin{array}{l}\text { The main objectives - preservations of } \\
\text { property, the analysis of a financial state }\end{array}$ \\
\hline $\begin{array}{l}\text { Основные задачи - сохранения имущества, } \\
\text { анализ финансового состояния }\end{array}$ & $\begin{array}{l}\text { It is entered for the term of no more than } 7 \\
\text { months }\end{array}$ \\
\hline Вводится на срок не более чем 7 месяцев & The main objective - restoration of solvency of \\
\hline $\begin{array}{lc}\text { Основная задача } & - \text { восстановление } \\
\text { платежеспособности } & \text { организации }\end{array}$ & $\begin{array}{l}\text { the organization and repayment of debt on the } \\
\text { schedule }\end{array}$ \\
\hline погашения задолженности по графику & It is entered for term more than 2 years \\
\hline Вводится на срок более чем 2 года & The main objective - restoration of solvency \\
\hline \begin{tabular}{lrrr} 
Основная задача & - & \multicolumn{2}{c}{ восстановление } \\
платежеспособности & & с & целью
\end{tabular} & $\begin{array}{l}\text { for the purpose of meeting requirements of } \\
\text { creditors in full }\end{array}$ \\
\hline $\begin{array}{l}\text { удовлетворения требований кредиторов в } \\
\text { полном объеме }\end{array}$ & $\begin{array}{l}\text { Term is entered no more than } 2 \text { years for the } \\
\text { term of no more than } 18 \text { months (it can be }\end{array}$ \\
\hline $\begin{array}{l}\text { Вводится на срок не более } 18 \text { месяцев } \\
\text { (может быть продолжен не более чем на } 6 \\
\text { месяцев), но суммарно с финансовым } \\
\text { оздоровлением срок не более } 2 \text { лет }\end{array}$ & $\begin{array}{l}\text { continued no more than for } 6 \text { months), but } \\
\text { totally with financial improvement } \\
\text { The main objective - proportional meeting } \\
\text { requirements of creditors due to sale of all }\end{array}$ \\
\hline Основная задача - соразмерное & property \\
\hline $\begin{array}{l}\text { удовлетворения требований кредиторов за } \\
\text { счет продажи всего имущества }\end{array}$ & $\begin{array}{l}\text { It is entered for } 1 \text { year (it can be prolonged no } \\
\text { more than for } 6 \text { months) }\end{array}$ \\
\hline $\begin{array}{l}\text { Вводится на } 1 \text { год (может быть продлено не } \\
\text { более чем на } 6 \text { месяцев) }\end{array}$ & $\begin{array}{l}\text { From this point the organization is considered } \\
\text { liquidated }\end{array}$ \\
\hline С этого момента организация считается & \\
\hline
\end{tabular}


Fig.1. The procedures applied in the case of insolvency (bankruptcy).

Let's consider the characteristic of the above-stated procedures and the purpose of their introduction in more detail. The law on bankruptcy provided the following procedures of bankruptcy: observation, financial improvement, external management, bankruptcy proceedings, settlement agreement.

1). Observation - the procedure applied in the case of bankruptcy to the debtor for ensuring safety of its property, carrying out the analysis of a financial condition of the debtor, drawing up the register of requirements of creditors and holding the first meeting of creditors. Observation begins with the moment of initiation by arbitration court of case of bankruptcy of the enterprises, continues during the determined period and comes to an end with the judgment about recognition of the enterprise by the bankrupt, either purpose of other procedures of bankruptcy, or refusal in recognition by the bankrupt. At an observation stage the interim manager holds the first meeting of creditors not less than in 10 days prior to the end of this procedure. At a meeting of creditors decisions on what will be the following procedure of bankruptcy who will keep the register of requirements of creditors who will be appointed the following receiver have to be made. The decision of the first meeting of creditors goes to the statement to arbitration court. The court cannot agree with it and take out other definition. This definition is taken out no later than 7 months from the moment of giving in court of the statement for recognition of the debtor by the bankrupt.

2). Financial improvement - the procedure applied in the case of bankruptcy to the debtor for restoration of its solvency and repayment of debt according to the schedule of repayment of debt. Financial improvement is entered according to the petition of founders of the debtor in the presence of the plan of financial improvement and the schedule of repayment of debt. Also ensuring performance of obligations of the debtor (pledge, bank guarantee, guarantee) of $120 \%$ of the debt sum has to be provided. The main objective of this procedure is to restore solvency of the debtor and to observe the schedule of repayment of debt, it is watched by the administrative managing director. Financial improvement is entered for a period of up to two years. 
3). External management - the procedure applied in the case of bankruptcy to the debtor for restoration of its solvency. This procedure is entered for a period of up to 18 months with possible extension for 6 months. From the moment of introduction of external management powers of the guide of the debtor stop, all documentation and the press are transferred to the external managing director. The moratorium on satisfaction of requirements of creditors which date of performance came before introduction of this procedure, except for requirements about collecting the salary, awards, about indemnification of life or health, about compensation of moral harm is imposed. The end of a procedure of external management is or transition to settlings with creditors (after accumulation of sufficient money or receiving them from founders or the third parties), or recognition of the debtor by the bankrupt and opening of bankruptcy proceedings.

4). Bankruptcy proceedings - the procedure applied in the case of bankruptcy to the debtor declared bankrupt for proportional satisfaction of requirements of creditors. This procedure opens after adoption by arbitration court of the decision on recognition of the debtor by the bankrupt. It is entered for one year with possible extension for 6 months.

5). The settlement agreement - the procedure applied in the case of bankruptcy at any stage of its consideration for determination of proceedings on bankruptcy by reaching an agreement between the debtor and creditors. The settlement agreement is concluded in writing and can be approved by arbitration court only after repayment of debt on requirements of creditors of the first and second stage. The settlement agreement can be concluded at any stage of case of bankruptcy between the debtor and his creditors; it is approved by the arbitration court ruling. It can provide payment by installments, reduction of payments, a compensation, exchange of requirements of creditors for actions (shares) in authorized capital, etc.

It should be noted that when considering the case about bankruptcy of the debtor - the citizen only such procedures as bankruptcy proceedings and the settlement agreement are applied.

\section{RESULTS}

Main objectives of introduction of the procedure of observation are ensuring safety of property of the debtor; analysis of a financial condition of the debtor and clarification of a possibility of rehabilitation of the debtor; protection of the rights and interests of all participants of process from illegal actions concerning each other. Therefore, the main task of observation is to reveal 
creditors of the debtor and to find his property, for the purpose of establishment of the fact of an opportunity (impossibility) of repayment of requirements of creditors.

Visually all procedure of observation can be presented in the figure 2 form.

\section{Observation Procedure:}

Removal of definition by arbitration court about introduction of observation and statements of the interim manager

10 days

The notice the debtor's head about introduction of observation of workers, founders (participants), the owner of property of the debtor - the unitary enterprise
Term unestablished

The direction to interim managers for publication of the notice of monitoring

\section{4 days}

The notification to interim managers of introduction of observation of all creditors revealed by him, except creditors before whom the debtor bears responsibility for infliction of harm of life or to health, moral harm, performance of obligations on payment of severance pays and compensation of the persons working according to the employment contract, performance of obligations on payment of remuneration under copyright

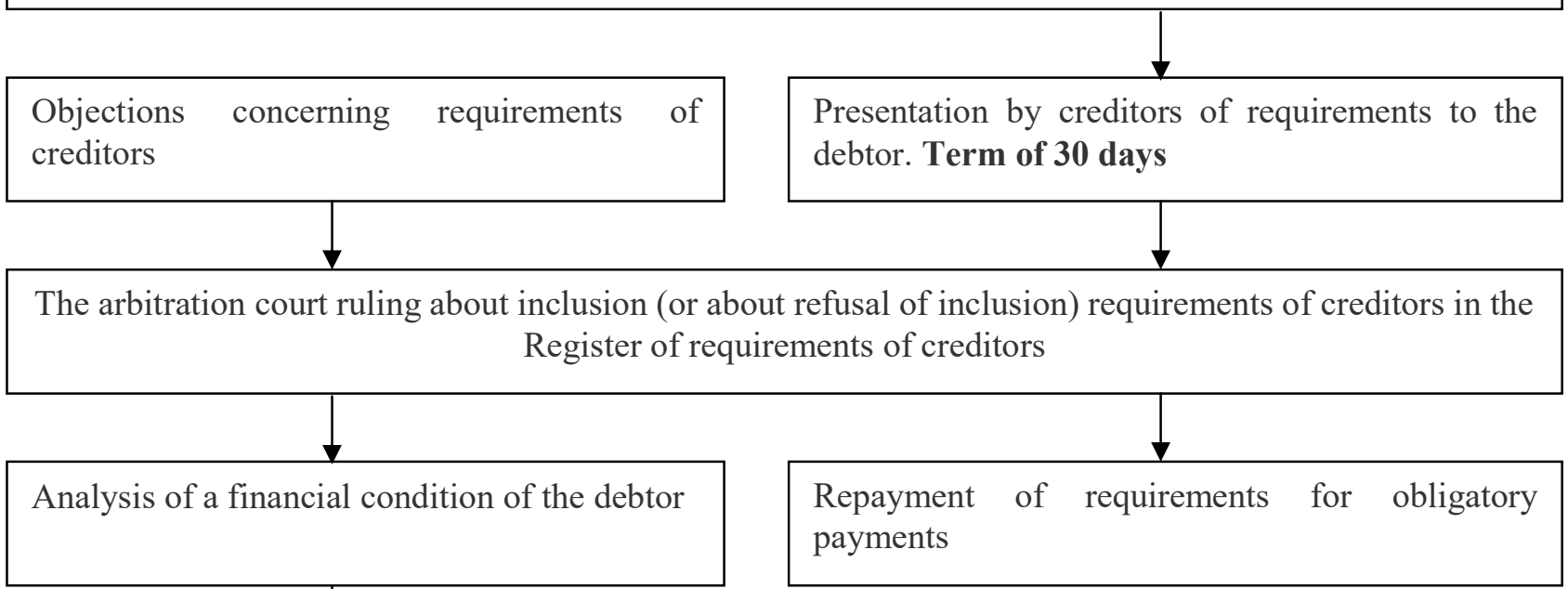

Analyzing the procedure of observation on the example of the Russian experience, R. Kalnan at

Holding the first meeting of creditors and making decision on the appeal to arbitration court with one of petitions, removal of definition by arbitration court and the bank guarantee for providing obligations

\section{End of observation}


because of the existing costs and impossibility of bystry decision-making in cases of insolvency, the preservation by the guide of the debtor of the powers attracting problems in relationship with the interim manager and complicating practical functioning of the procedure. Among minuses it should be noted also increase in the procedural expenses connected with payment of remuneration of the interim manager and the persons involved by it [7].

Existence of the procedure of observation in the Russian legislation is caused by the fact that Russia chose the system called by "a uniform entrance" to procedures of insolvency. The called on the basis of the solution of most of creditors to develop the decision either about rehabilitation, or about the liquidating procedure of insolvency on the basis of the full volume of information on business of the debtor, this procedure turned into the difficult procedural mechanism leading to delay in competitive process. All shortcomings and fears about which R. Kalnan in 2001 spoke completely were confirmed after time and were confirmed by practice of application of the law [5].

Miftakhutdinov R. T. states the critical point of view concerning application of the procedure of observation and considers that observation in most cases only slows down competitive process and increases costs of creditors and offers within the existing economic situation, completely to exclude the procedure of observation as inefficient and excessively expensive.

Thus, today, despite various points of view concerning the procedure of observation, it is designed to provide interests both creditors and the debtor by prevention of the possible conflicts. The correct application of actions of observation is capable to lead to achievement of balance of interests of the debtor and creditors, to create necessary prerequisites for adequate permission of case of bankruptcy.

\section{CONCLUSION}

Observation is the procedure of bankruptcy applied to the debtor for ensuring safety of its property, carrying out the analysis of a financial condition of the debtor, drawing up the Register of requirements of creditors and holding the first meeting of creditors. By the general rule the term of holding a procedure of observation cannot exceed seven months from the date of receipt in arbitration court of the statement for recognition of the debtor by the bankrupt.

The procedure of observation is carried out by the interim manager whose candidate is approved by arbitration court. Taking measures to ensuring safety of property of the debtor, carrying out 
the analysis of a financial condition of the debtor, identification of creditors of the debtor is among his fundamental obligations; maintaining register of requirements of creditors, notification of creditors of observation introduction, convocation and holding the first meeting of creditors. A monitoring procedure is introduced for the term of no more than seven months. Introduction of the procedure of observation involves approach of consequences both for the debtor, and for creditors. In general these consequences can be characterized as the consequences directed to an exception of a possibility of satisfaction of requirements of certain creditors, for example, execution of executive documents on property collecting stops, and also there come consequences in the form of restriction of legal capacity of the debtor, for protection of interests of creditors and safety of property of the debtor.

The report of the interim manager is formed by results of the carried-out procedure of observation and includes basic provisions, conclusions from the conclusion about a financial condition of the debtor; the conclusions about existence or about lack of the bases for contest of transactions of the debtor and justification of an opportunity or impossibility of restoration of solvency of the debtor, expediency of introduction of the subsequent procedures applied in the case of bankruptcy. Financial improvement, external management, bankruptcy proceedings and the settlement agreement can be the subsequent procedures. From the moment of making decision on introduction of one of above-mentioned procedures the period of observation is considered complete. However the interim manager continues to fulfill the duties before appointment external or the receiver.

Thus, today, despite various points of view concerning the procedure of observation, it is designed to provide interests both creditors, and the debtor by prevention of the possible conflicts. The correct application of actions of observation is capable to lead to achievement of balance of interests of the debtor and creditors, to create necessary prerequisites for adequate permission of case of bankruptcy.

\section{ACKNOWLEDGEMENTS}

The work is performed according to the Russian Government Program of Competitive Growth of Kazan Federal University. 


\section{REFERENCES}

1. Baldin K. V., Belugina V. V., Galditskaya S. N., Perederyaev I.I.Bankrotstvo of the enterprise: analysis, account and forecasting. M, "Dashkov and To", 2007, p 234.

2. Civil code of the Russian Federation (part one) of 30.11.1994 No. 51-FZ (edition of 23.07.2013)//Russian newspaper. - No. 238-239. - 08.12.1994.

3. Yershov I.V. Enterprise right / r. edition of I. V. Yershov, G. D. Otnyukov: the textbook for bachelors. - Moscow: Prospectus. - 2015. - page 114.

4. Commercial right: In two parts (part one) / / the Bus a stake.: A. Yu. Bushev, O. A. Gorodov, N. A. Dzhobava, etc.; Under the editorship of V. F. Popondopulo, V. F. Yakovleva; St. Petersburg State University. Law department, St. Petersburg branch of Institute of the state and right of RAS. - 3rd prod., re-ed. and comp., studies. - M. Yurist. - 2010. - page 175.

5. Miftakhutdinov R. T. Problems of optimization of legal regulation of the termination of legal entities without succession: Law PhD Thesis: 12.00.03//R. T. Miftakhutdinov. - M, 2011. - 31 pages.

6. Miftakhutdinov R. T. Cancellation of the procedure of observation as one of the main measures for improvement of the domestic legislation on bankruptcy and its consequences of de lege fedenda//R. T. Miftakhutdinov//20 years of the Constitution of the Russian Federation. - M.: Statute. - 2014. - page 288 - 294.

7. Miftakhutdinov R. T. Cancellation of the procedure of observation as one of the main measures for improvement of the domestic legislation on bankruptcy and its consequences of de lege fedenda//R. T. Miftakhutdinov//20 years of the Constitution of the Russian Federation. - M.: Statute. - 2014. - page 288 - 294.

8. Shershenevich G. F. Course of commercial law. M. 1912. Page 148.

9. Alpanda, S.a, Zubairy, S.b Addressing household indebtedness: Monetary, fiscal or macroprudential policy? // European Economic Review Volume 92, 1 February 2017, Pages 4773.

10. du Jardin, P. Dynamics of firm financial evolution and bankruptcy prediction // Expert Systems with Applications Volume 75, 1 June 2017, Pages 25-43.

11. Yang, J.-Q., Yang, Z.-J. Optimal consumption, investment and bankruptcy protection // Xitong Gongcheng Lilun yu Shijian System Engineering Theory and Practice Volume 33, Issue 4, April 2013, Pages 853-860. 
12. Grant, C., Koeniger, W. Redistributive taxation and personal bankruptcy in U.S. states // Journal of Law and Economics Volume 52, Issue 3, August 2009, Pages 445-467.

13. Chen, D., Zhao, J. The impact of personal bankruptcy on labor supply decisions // Review of Economic Dynamics Volume 26, 1 October 2017, Pages 40-61.

14. Chou, C.-H., Hsieh, S.-C., Qiu, C.-J. Hybrid genetic algorithm and fuzzy clustering for bankruptcy prediction Applied Soft Computing Journal Volume 56, 1 July 2017, Pages 298316.

15. Thomson, W. Game-theoretic analysis of bankruptcy and taxation problems: Recent advances // International Game Theory Review Volume 15, Issue 3, September 2013.

\section{How to cite this article:}

Khafizov A R, Salmina S V, Bakulina L T, Habibullin N E. Supervision as the procedure applicable in the case of bankruptcy. J. Fundam. Appl. Sci., 2017, 9(2S), 1121-1133. 